\section{IJ§ER}

ISSN: 2149-5939
International Journal of Social Sciences and Education Research

Online, http://dergipark.gov.tr/ijsser

Volume: 1(3), 2015

\title{
Relationship between anthropometric variables, respiratory function and bio-motoric properties in Turkish flat water canoe athletes ${ }^{1}$
}

\author{
Bircan Dokumac1 $^{2}$
}

\author{
Hayriye Çakır Atabek ${ }^{2}$
}

Received Date: 01 / 04 / 2015

Accepted Date: $01 / 07$ / 2015

\begin{abstract}
The flatwater canoeing competition is held in lake or pond that flow rate is constant. The traction and thrust force are expected to be at high level as well as excellent technique. Also, the 1000-m event demands high levels of both aerobic and anaerobic fitness. Additionally, sportive performance is affected by anthropometric characteristics. Therefore, the aim of this study was to determine the relationship between anthropometric variables, respiratory function, bio-motoric properties and 1000-m canoe performance. Eight male canoe athletes volunteered to participate in this study (mean age: $17.125 \pm 1.12$ years; height: $171.86 \pm 6.95 \mathrm{~cm}$; weight: $61.262 \pm 10.7 \mathrm{~kg}$; BMI: $20.623 \pm 2.41 \mathrm{~kg} / \mathrm{m}^{2}$ ). The canoe athletes underwent tests of anthropometric variables (height, weight, BMI, sitting height, arm span, sum of 8 skinfold, body fat percentage), respiratory function (FVC, FEV1, FEV1/FVC, PEF, $F E F_{25-75}$ and $M V V$ ), bio-motoric properties (right and left hand-grip strength, anaerobic power and isokinetic knee strength) and 1000-m canoe performance. Anaerobic power was estimated by using countermovement jump height. Bilateral concentric isokinetic strength of the knee extensors and flexors was evaluated at $60^{\circ} / \mathrm{s}$ and $240^{\circ} / \mathrm{s}$ using CSMI-Humac/NormTM-770 dynamometer (Humac Norm Testing and Rehabilitation System, USA). A Spirolab-III ergospirometer (Medical International Research, Italy) was used to measure pulmonary function. The results of the present study demonstrated that there were no significant relationship between anthropometric variables, respiratory function, bio-motoric properties and 1000-m canoe performance ( $p>0.05)$. A limited number of investigations focused on Turkish canoe athletes encourage us to design this study. Lack of training experience of participants may affect the results. Moreover, the small sample size is limitation of the present study.
\end{abstract}

Keywords: Canoe, isokinetic strength, hand-grip, respiratory function, anaerobic power

\section{Introduction}

Flat-water canoeing race became an Olympic discipline in 1936 in Berlin. The Flat-water canoeing races involve single seat kayaks (K-1), double seated kayaks (K-2), and four seated kayaks (K-4) (Hagner-Derengowska et al., 2014). In the flat-water canoeing events, the upper body is predominantly used to make the trunk rotates from seated position and the movement involves concurrent trunk rotation and stabilization (Mann and Kearney, 1979). Previous studies suggest that flat-water canoeing events require high maximal aerobic and anaerobic capacities and upper body muscle strength (Bishop, 2000; McKean and Burkett, 2010). Also, optimal performance in flat-water canoeing events is result of the complex blend of psychological, physiological, anthropometric and biomechanical factors (Bishop, 2000).

Isokinetic strength is assessed by isokinetic dynamometer that allow to measure muscle power in dynamic movement. Canoe athletes exert force while sitting position and the muscle strength of lower extremity is important as well as upper extremity. The study which evaluated canoe and kayak paddlers' various performance reported that performance and isokinetic knee strength were

${ }^{1}$ This study was presented as an oral presentation at ICSER-International Conference on Social Sciences and Education Research, Turkey, 2015.

${ }^{2}$ Anadolu University, Sports Science Faculty, Department of Coaching Training in Sports, email;bircanakdogan@gmail.com 
Dokumac1, B., Çakır Atabek, H. (2015). Relationship between anthropometric variables, respiratory function and bio-motoric properties in Turkish flat water canoe athletes. International Journal of Social Sciences and Education Research, 1 (3), 758-767.

positively correlated (Akça and Müniroglu, 2008; Hamano et al., 2015). Hamano et al. (2015) showed that canoe performance was significantly correlated with isokinetic strength, hand-grip strength and anaerobic power (Hamano et al., 2015). Similarly, other study demonstrated that there were a significant relationship between $200 \mathrm{~m}, 500 \mathrm{~m}$ and $1000 \mathrm{~m}$ performance time, anthropometric variables and upper body muscle strength (Akça and Müniroglu, 2008).

Considering the limited scientific data in Turkish canoe and kayak athletes, the purpose of this study was to investigate some physical, anthropometric, strength and pulmonary function characteristics and the relationship of these characteristics with $1000 \mathrm{~m}$ canoe performance time. The anthropometric characteristic were evaluated by height, body mass, body mass index, sitting height, arm span, sum of 8 skinfold and body fat percentage, the strength characteristics were evaluated by isometric hand grip (normalized for body mass), anaerobic power estimated by counter movement jump and isometric strength of knee flexors and extensors, additionally, pulmonary function characteristic were evaluated by forced vital capacity (FVC), forced expiratory volume in one second (FEV1), the ratio of FEV1 to FVC (the Tiffeneau index), the forced expiratory flow $\left(\mathrm{FEF}_{25-75}\right)$, the peak expiratory flow (PEF) and maximum voluntary ventilation (MVV). Due to the lack of scientific data about Turkish flat-water canoeists' physiological and performance characteristics, once identified these characteristics may be used for talent identification and assisted the coach for training strategies.

\section{Methods}

\subsection{Participants}

Eight healthy male canoeists volunteered to participate in this study. All participants were members of the same team who had trained for 2.4 hours per day, five days a week. None of the participants had medical history, leg or arm injury, cardiovascular and pulmonary diseases. At the beginning of the study all participants were informed about possible risks and benefits of the study and written consents were obtained from them and from their parents or legal guardian. The study was conducted in accordance with the Declaration of Helsinki for experiments involving humans.

\subsection{Experimental overview}

All participants visited the laboratory two times. During visit one, the subjects' anthropometric values, counter movement jump performance and isokinetic strength of the knee were measured. On visit 2, the hand grip strength and the pulmonary functions were evaluated. The participants underwent a $1000 \mathrm{~m}$ canoe performance trial over a measured flatwater course, under race conditions.

\subsection{Anthropometry}

Height and sitting height were measured using a stadiometer (Holtain, Britain) and body mass was estimated by bioelectrical impedance analyzer (BIA) (Tanita MC-180-MA, Japan). Arm span was measured using a metal anthropometric tape, between the distal ends of the third fingers, as subjects stood with outstretched arms in a horizontal plane. The subjects' 8 skinfold sites (brachii, biceps brachii, suprailiac, supraspinale, abdominal, subscapular, anterior thigh, and calf skinfold thickness) were measured using a skinfold caliper (Holtain, ltd, England) to the nearest 0.2 $\mathrm{mm}$. The median of three values was used for data analysis. Body density was predicted using the 
Dokumacı, B., Çakır Atabek, H. (2015). Relationship between anthropometric variables, respiratory function and bio-motoric properties in Turkish flat water canoe athletes. International Journal of Social Sciences and Education Research, 1 (3), 758-767.

equation of Durnin and Womersley (Durnin and Womersley, 1974) (Formula 1) and body fat was estimated using the equation of Siri (Siri, 1956) (Formula 2). Additionally the body mass index (BMI) was calculated (Formula 3).

Body density $=1.1533-0.0643 \log \Sigma 4$ (boys)

Formula 1

$\Sigma 4$ : Sum of 4 skinfold as suprailliac, biceps, subscapular and triceps

(Durnin and Womersley,1974)

Body fat $=((4.95 /$ body density $)-4.5) \times 100$

Formula 2

(Siri,1956)

$\mathrm{BMI}=$ Weight $(\mathrm{kg}) / \operatorname{Height}(\mathrm{m})^{2}$

Formula 3

\subsection{Counter movement jump tests and anaerobic power}

All participants started with a standardized warm-up of 5-7 minute of cycling at 55-60 rpm against no load (894 Ea, Peak Bike by Monark AB, Sweden) and 5-7 minute of stretching. Following the warm-up, subjects rested for 5-min. After a familiarization session (learning the proper techniques of the jump condition) each participant performed three maximal voluntary counter movement jumps (CMJ) and the best value of the three trials was used for further analysis. The CMJ was performed using a dedicated force platform (Fusion Sport, Old, Australia) from an upright standing position, with the hands fixed on the hips and with a counter movement preparatory phase. Sufficient recovery time was given among trials (more than 2 minutes). The power output $\left(\mathrm{CMJ}_{\text {power }}\right)$ value was calculated using the following formula (Rogers, 1990).

$\mathrm{CMJ}_{\text {power }}(\mathrm{kg} . \mathrm{m} / \mathrm{s})=\sqrt{ } 4.9 \times$ body weight $(\mathrm{kg}) \times \sqrt{\text { jump height }(\mathrm{m}) \quad \text { Formula } 4}$

\subsection{Isokinetic strength}

Bilateral concentric isokinetic strength of the knee extensors and flexors was measured using the CSMI-Humac/NormTM-770 model (Humac Norm Testing and Rehabilitation System, USA). Before each testing session, the dynamometer was calibrated in accordance with the manufacturer's recommendations. Knee extension and flexion were performed with the subjects in an upright seated position, with their hands gripping the sides of the dynamometer chair. Stabilizing straps were placed around the thorax, pelvis and the thigh. The resistance shin pad was placed at a level just above the medial malleolus. Peak isokinetic concentric knee extension and flexion torque of both legs were evaluated at 2 angular velocities: 60 , and $240 \%$ s. Contractions were performed through a range of 0 - 90 (full extension defined as $0^{\circ}$ ). Subjects were instructed to complete 3 submaximal trials at 60 and 5 submaximal trials at $240 \%$ s angular velocity for familiarization and warm-up purpose. Subjects then performed 5 maximal repetitions of knee extension and flexion at $60 \%$ s angular velocity and 30 maximal repetitions at $240 \%$ s angular velocity. A $30-\mathrm{s}$ time interval was provided between familiarization and test session (Çakır-Atabek et al., 2009; Tsiokanos et al., 2002) whereas a 2-min rest period was given between each test velocity (ÇakırAtabek et al., 2009; Malliou et al., 2003). In addition, a break of at least 2-min was given when the machine setting was changed for the opposite leg. The order of testing was randomized for the dominant and non-dominant legs. Verbal encouragements and visual feedback were given by investigator to all participants to help them concentrate on the quality of their movements. The 
Dokumacı, B., Çakır Atabek, H. (2015). Relationship between anthropometric variables, respiratory function and bio-motoric properties in Turkish flat water canoe athletes. International Journal of Social Sciences and Education Research, 1 (3), 758-767.

greatest peak torque $(\mathrm{Nm})$ for knee extension and flexion (out of the 5 and 30 trials in each velocity) and fatigue index (FI) and total work (TW) were calculated automatically by the Hu$\operatorname{mac} \AA / 2004$ and served as the outcome measure.

\subsection{Hand-grip isometric strength}

Each participant was given a brief demonstration and verbal instructions for the hand-grip test using the Takei T.K.K.5101 digital hand-grip dynamometer (Takei Scientific Instruments Co. Ltd, Tokyo, Japan). If necessary the grip opening was adjusted according to the subject's hand size. The test was conducted for both the dominant and non-dominant hand, in standing, with shoulder adducted and neutrally rotated and the wrist and the elbow in full extension. The dynamometer was held freely without support, not touching the subject's trunk (Koley et al., 2011). Three trials were allowed with sufficient recovery period and the highest score was recorded in kilograms $(\mathrm{kg})$ as peak grip strength.

\subsection{Pulmonary functions}

A Spiro lab III ergo spirometer (Medical International Research) was used to measure pulmonary functions. The spirometric values were measured when the subjects were in seated position. Wearing a nose clip, and following a maximal inspiration, subjects performed a maximal expiration for the determination of forced vital capacity (FVC), forced expiratory volume in one second (FEV1), the ratio of FEV1 to FVC (the Tiffeneau index), the forced expiratory flow $\left(\mathrm{FEF}_{25-75}\right)$, the peak expiratory flow (PEF) and maximum voluntary ventilation (MVV).

\section{8. $1000 \mathrm{~m}$ Canoe performance}

The participants underwent a $1000 \mathrm{~m}$ canoe performance trial over a measured flatwater course, under race conditions.

\subsection{Statistical analysis}

All values were presented as mean \pm standard deviation. The correlations between anthropometric variables (age, height, body mass, body mass index, sitting height, arm span, sum of 8 skinfold and body fat percentage), respiratory function (FVC, FEV1, FEV1/FVC, PEF, FEF 25-75 and $M V V$ ) and bio-motoric properties (hand grip strength, anaerobic power and isokinetic strength) was evaluated using the Pearson Product Moment Correlation analysis. All analyses were executed using the SPSS for windows version 16.0 and statistical significance was set at $p$ $<0.05$.

\section{Results}

General physical and anthropometric characteristics and correlation analysis of these values with $1000 \mathrm{~m}$ canoe performance time of the participants are presented in Table 1. The results indicated that there were no significant correlations between anthropometric variables and $1000 \mathrm{~m}$ canoe performance time $(\mathrm{p}>0.05)$.

The hand grip strength and the anaerobic power values and correlation analysis of these values with $1000 \mathrm{~m}$ canoe performance time of the participants are presented in Table 2 . There were no 
Dokumacı, B., Çakır Atabek, H. (2015). Relationship between anthropometric variables, respiratory function and bio-motoric properties in Turkish flat water canoe athletes. International Journal of Social Sciences and Education Research, 1 (3), 758-767.

significant correlations between hand grip strength (for both absolute and relative values), anaerobic power estimated by vertical jump performance and $1000 \mathrm{~m}$ canoe performance time $(\mathrm{p}>0.05)$.

Table 1. General physical and anthropometric characteristics of the flat water canoe athletes $(n=8)$.

\begin{tabular}{|c|c|c|c|}
\hline Variables & Mean \pm sd & $\begin{array}{c}\text { Minimum - Maxi- } \\
\text { mum }\end{array}$ & $\begin{array}{c}\text { Correlation with } 1000 \text { m per- } \\
\text { formance }(r)\end{array}$ \\
\hline Age (years) & $17.125 \pm 1.12$ & $15.00-18.00$ & -0.121 \\
\hline Height $(\mathrm{cm})$ & $171.86 \pm 6.95$ & $160.1-181.8$ & 0.210 \\
\hline Body mass (kg) & $61.262 \pm 10.7$ & $50.85-78.50$ & 0.238 \\
\hline $\operatorname{BMI}\left(\mathrm{kg} / \mathrm{m}^{2}\right)$ & $20.623 \pm 2.41$ & $18.48-24.95$ & 0.180 \\
\hline Sitting Height $(\mathrm{cm})$ & $91.231 \pm 3.48$ & $84.35-94.60$ & 0.125 \\
\hline $\operatorname{Arm} \operatorname{Span}(\mathrm{cm})$ & $174.00 \pm 8.51$ & $161.3-184.7$ & 0.148 \\
\hline Sum of 8 Skinfold $(\mathrm{mm})^{*}$ & $74.783 \pm 21.6$ & $47.87-103.6$ & 0.231 \\
\hline Body Fat Percentage (\%) & $17.465 \pm 3.08$ & $13.81-21.81$ & 0.283 \\
\hline $\begin{array}{l}\text { Best canoe performance } \\
\text { K1 } 1000 \text { (min:s:ss) }\end{array}$ & $\begin{array}{c}05: 48: 28 \pm \\
00: 49: 17\end{array}$ & $04: 45: 33-06: 58: 39$ & \\
\hline
\end{tabular}

BMI: Body mass index

*Sum of triceps brachii, biceps brachii, suprailiac, supraspinale, abdominal, subscapular, anterior thigh, and calf skinfold thickness.

Table 2. The hand-grip strength and the anaerobic power values of the flat water canoe athletes $(\mathrm{n}=8)$.

\begin{tabular}{lccc}
\hline \multicolumn{1}{c}{ Variables } & Mean \pm sd & Minimum - Maximum & $\begin{array}{c}\text { Correlation with 1000 m per- } \\
\text { formance (r) }\end{array}$ \\
\hline Hand-grip of right arm $(\mathrm{kg})$ & $38.06 \pm 6.35$ & $30.40-45.00$ & -0.235 \\
\hline $\begin{array}{l}\text { Normalized hand -grip } \\
\text { of right arm (kg.kg })\end{array}$ & $0.619 \pm 0.11$ & $0.420-0.730$ & -0.466 \\
\hline Hand-grip of left arm (kg) & $37.29 \pm 5.09$ & $30.00-44.90$ & 0.022 \\
\hline $\begin{array}{l}\text { Normalized hand -grip } \\
\text { of left arm (kg.kg })\end{array}$ & $0.605 \pm 0.08$ & $0.480-0.700$ & -0.369 \\
\hline Anaerobic power (kg.m/s)* & $77.45 \pm 12.8$ & $62.70-95.82$ & 0.181 \\
\hline
\end{tabular}

*Anaerobic power (kg.m/s) estimated by vertical jump performance

The pulmonary function tests values and correlation analysis of these values with $1000 \mathrm{~m}$ canoe performance time of the canoe athletes are presented in Table 3. The results demonstrated that there were no significant correlations between FVC, FEV1, FEV1/FVC, PEF, FEF $25-75$ and MVV and $1000 \mathrm{~m}$ canoe performance time $(\mathrm{p}>0.05)$. 
Dokumacı, B., Çakır Atabek, H. (2015). Relationship between anthropometric variables, respiratory function and bio-motoric properties in Turkish flat water canoe athletes. International Journal of Social Sciences and Education Research, 1 (3), 758-767.

Table 3. Pulmonary function tests values of the flat water canoe athletes $(\mathrm{n}=8)$.

\begin{tabular}{lccc}
\hline \multicolumn{1}{c}{ Variables } & Mean $\pm \mathbf{s d}$ & Minimum - Maximum & $\begin{array}{c}\text { Correlation with 1000 m } \\
\text { performance (r) }\end{array}$ \\
\hline $\mathrm{FVC}(\mathrm{L})$ & $5.088 \pm 0.75$ & $3.800-6.140$ & 0.533 \\
\hline $\mathrm{FEV} 1(\mathrm{~L})$ & $4.077 \pm 0.92$ & $2.770-5.150$ & -0.111 \\
\hline $\mathrm{FEV} 1 / \mathrm{FVC}(\%)$ & $80.36 \pm 15.1$ & $57.60-95.10$ & -0.467 \\
\hline $\mathrm{PEF}(\mathrm{L} / \mathrm{sn})$ & $5.948 \pm 2.30$ & $2.860-8.870$ & -0.304 \\
\hline $\mathrm{FEF}_{25-75}(\mathrm{~L} / \mathrm{sn})$ & $4.387 \pm 1.45$ & $2.600-5.830$ & -0.248 \\
\hline $\mathrm{MVV}_{(\mathrm{L})}$ & $152.1 \pm 19.9$ & $125.0-187.4$ & 0.439 \\
\hline
\end{tabular}

Moreover, the values of isokinetic strength of knee extensor and flexors (peak torque, fatigue index and total work measured at $240 \%$ s) and correlation analysis of these values with $1000 \mathrm{~m}$ canoe performance time of the canoe athletes are presented in Table 4. No significant correlation was determined between these variables $(\mathrm{p}>0.05)$.

Table 4. Isokinetic knee strength values of the flat water canoe athletes $(n=8)($ in $N m)$.

\begin{tabular}{llcc}
\hline \multicolumn{1}{c}{ Variables } & Mean \pm sd & $\begin{array}{c}\text { Correlation with 1000 m per- } \\
\text { formance (r) }\end{array}$ \\
\hline $60^{\circ} / \mathrm{s}$ & Right knee extension & $122.66 \pm 20.07$ & -0.167 \\
& Right knee flexion & $114.33 \pm 28.00$ & 0.054 \\
& Left knee extension & $164.37 \pm 98.41$ & 0.537 \\
& Left knee flexion & $151.00 \pm 91.19$ & 0.443 \\
\hline $240 \% \mathrm{~s}$ & Right knee extension & $123.50 \pm 49.89$ & 0.597 \\
& Right knee flexion & $153.75 \pm 104.7$ & 0.453 \\
& Left knee extension & $145.50 \pm 119.9$ & 0.498 \\
& Left knee flexion & $150.75 \pm 94.11$ & 0.464 \\
\hline $240 \% \mathrm{~s}$ & FI of right knee extension & $23.625 \pm 28.44$ & -0.673 \\
& FI of right knee flexion & $26.375 \pm 9.826$ & -0.195 \\
& FI of left knee extension & $24.000 \pm 15.91$ & -0.353 \\
& FI of left knee flexion & $27.250 \pm 9.145$ & -0.468 \\
\hline $240^{\circ} / \mathrm{s}$ & TW of right knee extension & $2593.87 \pm 1984.2$ & 0.530 \\
& TW of right knee flexion & $2938.00 \pm 2306.4$ & 0.437 \\
& TW of left knee extension & $2706.75 \pm 2298.2$ & 0.520 \\
& TW of left knee flexion & $2779.50 \pm 1822.3$ & 0.482 \\
\hline
\end{tabular}

FI: Fatigue index; TW: Total work

\section{Discussion}

The purpose of this study was to investigate some physical, anthropometric, strength and pulmonary function characteristics and the relationship of these characteristics with $1000 \mathrm{~m}$ canoe performance time of Turkish canoeists. The results of the present study indicated that measured anthropometric, strength and pulmonary function characteristics were not significantly correlated with $1000 \mathrm{~m}$ canoe performance time in Turkish flat water canoe athletes.

Anthropometric characteristics of the athlete is a very important factor to impact canoe performance (Robinson et al., 2002). A lots of physical and physiological parameters such as anthropometric, strength, aerobic and anaerobic power factors contribute to performance in flat-water 
Dokumacı, B., Çakır Atabek, H. (2015). Relationship between anthropometric variables, respiratory function and bio-motoric properties in Turkish flat water canoe athletes. International Journal of Social Sciences and Education Research, 1 (3), 758-767.

canoeist (Fry and Morton, 1991; Sklad et al., 1994). Anthropometric characteristics are important factors because of lengths of some limbs could affect performance in rowing or canoe (Bishop, 2000; Robinson et al., 2002; Shephard, 1987; Sklad et al., 1994). Ackland et al. (2003) suggested that both male and female canoeist/paddlers have a homogenous shape and size (Ackland et al., 2003). Top level athletes have less body fat and more lean body mass (Ackland et al., 2003; Sitkowski, 2002). Similarly, Akça and Müniroğlu (2008) reported that Turkish flat-water paddlers' anthropometric variables were close to the British U.S. national team athletes' anthropometric variables (Akça and Müniroglu, 2008). Also, Humphries et al. (2000) reported that amateur canoeist anthropometric values were the same as the elite kayakers (Humphries et al., 2000). Additionally, Hamano et al. (2015) showed that there was a positive relation between anthropometric variables and performance time (Hamano et al., 2015). The results of the present study is not consistent with the results of the mentioned studies (Akça and Müniroglu, 2008; Hamano et al., 2015). First, higher values were reported for the anthropometrics characteristic (Akça and Müniroglu, 2008) compare to our data (Table 1). The participants of the present study were younger $(17.125 \pm 1.12$ vs $21.54 \pm 2.16$ (years)), shorter $(171.86 \pm 6.95$ vs $178.89 \pm 6.8(\mathrm{~cm}))$ and lightweight $(61.262 \pm 10.7 \mathrm{vs} 77.4 \pm 8.108(\mathrm{~kg}))$ than participants volunteered in mentioned study conducted by Akça and Müniroğlu (2008). This may explain the conflicting results of the study.

Assessment of athlete's anthropometric characteristics and fitness level could show to coach or specialist how they can improve performance or use talent identification. For this reason, finding out relationship between real sport specific performance and anthropometric characteristics or fitness level is very important to use this information in practice. Considering the limitation of the specific sport and age group, we can only compare our data to those of similar sports and different mostly older age group. Someren and Palmer (2003) reported that there was a significant correlation between $200 \mathrm{~m}$ canoe performance and anthropometric variables such as body mass, the lean body mass, sum of skinfolds and body fat percentage (Someren and Palmer, 2003). Similarly, $1000 \mathrm{~m}$ kayak performance time was significantly correlated with chest girth (Fry and Morton, 1991). Kerr et al. (2008) reported that some physiological variables $\left(\mathrm{VO}_{2 \max }\right.$, Heart rate etc.) were significantly correlated with $1000 \mathrm{~m}$ performance time and they suggested that coach can use the performance time in talent identification (Kerr et al., 2008). The results of the present study demonstrated that the anthropometric characteristics were not significantly correlated with $1000 \mathrm{~m}$ canoe performance time. We measured only $1000 \mathrm{~m}$ canoe performance time and this limits our discussion.

In terms of fitness, canoe athletes have high aerobic and anaerobic capacities (Bishop, 2000) also, they lift the weights as much as other athletes who participated in required upper limb muscle strength (Nakagaki et al., 2008). Tesch (1983) suggested that elite paddlers had a well-developed anaerobic capacity for upper body (Tesch, 1983). Also, the another study reported that paddlers could cope with at least twice the anaerobic power than sedentary subjects (Pendergast et al., 1979). On the other hand, Pyke et al. (1973) suggested that to assess to work the only hand/arm cranking on an ergometer does not closely simulate the movements required on the water. Specific ergometer may use to allow for an accurate comparative analysis (Pyke et al., 1973). In the current study we estimated the anaerobic power by CMJ height. The results indicated that neither isometric hand grip strength nor anaerobic power was correlated with $1000 \mathrm{~m}$ canoe performance time. The study's sample size was small and this is one of the limitation of the present study. The teams that we work with included only 8 experienced athletes on their roster. 
Dokumacı, B., Çakır Atabek, H. (2015). Relationship between anthropometric variables, respiratory function and bio-motoric properties in Turkish flat water canoe athletes. International Journal of Social Sciences and Education Research, 1 (3), 758-767.

The functional state of the respiratory system can be conventionally determined by measuring the lung volumes and capacities (Atan et al., 2013). Numerous studies reported that there were no significant differences between groups of athletes engaged in different sports for pulmonary function properties (Kara et al., 2010; Kürkçü et al., 2009; Moğulkoç et al., 1997; Triki et al., 2013). Moğulkoç et al. (1997) recorded that the FEV1 values of control, basketball and track and field athletes groups were $86.26 \pm 4.20 \mathrm{~L}, 86.56 \pm 4.21 \mathrm{~L}$ and $88.29 \pm 3.90 \mathrm{~L}$ respectively and added that there were no significant differences between groups (Moğulkoç et al., 1997). Similarly FVC, FEV1, PEF and FEV1/FVC values were compared between group of athletes engaged in different sport training and it was demonstrated that there were no significant differences between groups [wrestling vs. basketball (Kara et al., 2010); football vs. badminton (Kürkçü et al., 2009); football vs. judo (Triki et al., 2013)]. As it can be seen the values of pulmonary function characteristics recorded in the current study are similar to those reported in aforementioned studies. Additionally, the values of pulmonary function characteristics recorded in the current study are near to those reported by Çakır-Atabek (2015) which values were obtained from volleyball, basketball, handball, badminton, futsal and football male players (Çakır-Atabek, 2015). The results of the current study demonstrated that the pulmonary function characteristics were not correlated with $1000 \mathrm{~m}$ canoe performance time. Lack of research data makes it difficult to discuss these findings.

\section{Acknowledgements}

The authors would like to thank all the participants for their voluntary participation.

\section{References}

Ackland, T. R., Ong, K., Kerr, D., \& Ridge, B. (2003). Morphological characteristics of Olympic sprint canoe and kayak paddlers. Journal of Science and Medicine in Sport, 6(3), 285-294.

Akca, F., \& Muniroglu, S. (2008). Anthropometric-somatotype and strength profiles and on-water performance in Turkish elite kayakers. International Journal of Applied Sports Sciences, 20(1), 22-34.

Çakır-Atabek, H., Sönmez, G. A., \& Yilmaz, I. (2009). The relationship between isokinetic strength of knee extensors/flexors, jumping and anaerobic performance. Isokinetics and exercise science, 17(2), 79-83.

Çakır-Atabek, H. (2015). Farkli spor branşlarinda antrenman yapan 15-17 yaş öğrencilerin bazi solunum fonksiyonlarinin ve biyomotorik özelliklerinin incelenmesi. İönü Üniversitesi Beden Eğitimi ve Spor Bilimleri Dergisi, 2(1), 1-16.

Atan, T., Akyol, P., \& Çebi, M. (2013). Bireysel sporlarla uğraşan yıldızlar kategorisindeki sporcuların solunum fonksiyonlarının karşılaştırılması. Dicle Tip Dergisi, 40(2).

Bishop, D. (2000). Physiological predictors of flat-water kayak performance in women. European Journal of Applied Physiology, 82(1-2), 91-97.

Durnin, J., \& Womersley, J. (1974). Body fat assessed from total body density and its estimation from skinfold thickness: measurements on 481 men and women aged from 16 to 72 years. British journal of nutrition, 32(01), 77-97.

Fry, R., \& Morton, A. R. (1991). Physiological and kinanthropometric attributes of elite flatwater kayakists. Medicine and Science in Sports and Exercise, 23(11), 1297-1301.

Hagner-Derengowska, M., Hagner, W., Zubrzycki, I. Z., Krakowiak, H., Słomko, W., Dzierżanowski, M., \& Wiącek-Zubrzycka, M. (2014). Body structure and composition of canoeists and kayakers: Analysis of junior and teenage Polish National Canoeing Team. Biology of Sport, 31(4), 323. 
Dokumacı, B., Çakır Atabek, H. (2015). Relationship between anthropometric variables, respiratory function and bio-motoric properties in Turkish flat water canoe athletes. International Journal of Social Sciences and Education Research, 1 (3), 758-767.

Hamano, S., Ochi, E., Tsuchiya, Y., Muramatsu, E., Suzukawa, K., \& Igawa, S. (2015). Relationship between performance test and body composition/physical strength characteristic in sprint canoe and kayak paddlers. Open access journal of sports medicine, 6, 191.

Humphries, B., Abt, G. A., Stanton, R., \& Sly, N. (2000). Kinanthropometric and physiological characteristics of outrigger canoe paddlers. Journal of sports sciences, 18(6), 395-399.

Kara, E., Özal, M., \& Yavuz, H. (2010). Elit güreşçi ve basketbolcuların kan ve solunum parametrelerinin karşılaştırılması. Selçuk Üniversitesi Beden Eğitimi ve Spor Bilim Dergisi, 12(1), 36-41.

Kerr, R. M., Spinks, W., Leicht, A. S., Sinclair, W., \& Woodside, L. (2008). Comparison of physiological responses to graded exercise test performance in outrigger canoeing. Journal of sports sciences, 26(7), 743-749.

Koley, S., Kaur, S., \& Sandhu, J. (2011). Correlations of handgrip strength and some anthropometric variables in Indian inter-university female handball players. Sport Science Review, 20(3-4), 57-68.

Kürkçü, R., Afyon, Y. A., Yaman, Ç., \& Özdağ, S. (2009). 10-12 yaş grubundaki futbolcu ve badmintoncularda bazı fiziksel ve fizyolojik özelliklerinin karşılaştırılması. Uluslararası İnsan Bilimleri Dergisi, 6(1), 547-556.

Malliou, P., Ispirlidis, I., Beneka, A., Taxildaris, K., \& Godolias, G. (2003). Vertical jump and knee extensors isokinetic performance in professional soccer players related to the phase of the training period. Isokinetics and exercise science, 11(3), 165-169.

Mann, R. V., \& Kearney, J. T. (1979). A biomechanical analysis of the Olympic-style flatwater kayak stroke. Medicine and Science in Sports and Exercise, 12(3), 183-188.

McKean, M. R., \& Burkett, B. (2010). The relationship between joint range of motion, muscular strength, and race time for sub-elite flat water kayakers. Journal of Science and Medicine in Sport, 13(5), 537542 .

Moğulkoç, R., Baltacı, A., Keleştimur, K., Koç, H., \& Özdemirli, S. (1997) 16 yaş grubu sporcu genç kızlarda Max VO2 ve bazı solunum parametreleri üzerine bir araştırma. Beden Eğitimi ve Spor Bilimleri Dergisi, II (1), 9, 1997.

Nakagaki, K., Yoshioka, T., \& Nabekura, Y. (2008). The relative contribution of anaerobic and aerobic energy systems during flat-water kayak paddling. Japanese Journal Of Physical Fitness And Sports Medicine, 57(2), 261-269.

Pendergast, D., Cerretelli, P., \& Rennie, D. (1979). Aerobic and glycolytic metabolism in arm exercise. Journal of Applied Physiology, 47(4), 754-760.

Pyke, F., Baker, J., Hoyle, R., \& Scrutton, E. (1973). Metabolic and circulatory responses to work on a canoeing and bicycle ergometer. AJSM Research Edition, 5(6), 22-31.

Robinson, M. G., Holt, L. E., \& Pelham, T. W. (2002). The technology of sprint racing canoe and kayak hull and paddle designs. International Sports Journal, 6(2), 68.

Rogers, C. (1990). Exercise physiology laboratory manual. Dubuque: Wm C Brown Publishers.

Shephard, R. J. (1987). Science and medicine of canoeing and kayaking. Sports medicine, 4(1), 19-33.

Siri, W. E. (1956). The gross composition of the body. Adv Biol Med Phys, 4(239-279), 513.

Sitkowski, D. (2002). Some indices distinguishing Olympic or world championship medallists in sprint kayaking. Biology of Sport, 19(2), 133-147. 
Dokumacı, B., Çakır Atabek, H. (2015). Relationship between anthropometric variables, respiratory function and bio-motoric properties in Turkish flat water canoe athletes. International Journal of Social Sciences and Education Research, 1 (3), 758-767.

Sklad, M., Krawczyk, B., \& Majle, B. (1994). Body build profiles of male and female rowers and kayakers. Biology of Sport, 11(4), 249-256.

Someren, K. V., \& Palmer, G. S. (2003). Prediction of 200-m sprint kayaking performance. Canadian journal of applied physiology, 28(4), 505-517.

Tesch, P. A. (1983). Physiological characteristics of elite kayak paddlers. Canadian journal of applied sport sciences. Journal canadien des sciences appliquees au sport, 8(2), 87-91.

Triki, M., Rebai, H., Shamssain, M., Masmoudi, K., Fellmann, N., Zouari, H., \& Tabka, Z. (2013). Comparative study of aerobic performance between Football and Judo Groups in Prepubertal boys. Asian journal of sports medicine, 4(3), 165.

Tsiokanos, A., Kellis, E., Jamurtas, A., \& Kellis, S. (2002). The relationship between jumping performance and isokinetic strength of hip and knee extensors and ankle plantar flexors. Isokinetics and exercise science, 10(2), 107-116. 